American Journal of Applied Sciences 8 (1): 82-91, 2011

ISSN 1546-9239

(C) 2010 Science Publications

\title{
Mechanical Strength and Durability Properties of High Performance Mortar Containing Densified Silica Fume
}

\author{
Cheah Chee Ban and Mahyuddin Ramli \\ Department Building Technology, School of Housing, \\ Building and Planning, University Sains Malaysia, 11800 Penang, Malaysia
}

\begin{abstract}
Problem statement: Numerous data and information on pozzolanic reaction and microfiller properties of silica fume were derived from laboratory investigation on silica fume in undensified form. Currently, due to low bulk density of undensified silica fume which poses problem in transportation and handling of the material, silica fume are commercially supplied in densified form. Densification process used to increase bulk density of fresh silica fume has resulted in agglomeration of the silica fume particles hence altering its effective particle size and distribution which may affect its hydration and microfiller properties. However, very few studies have been performed to study hydration properties of cementitious mixtures containing Densified Silica Fume (DSF) as supplementary binder. Approach: Characterization of physical and chemical properties of DSF was performed. Compressive strength of high performance mortar mixtures containing DSF as partial cement replacement material at various level of replacement ranging between 0-25\% was assessed. Water absorption and intrinsic air permeability of hardened mortars was evaluated at the age of 28 days. Results: Incorporation of DSF at replacement level up to 25\% produced mortar with higher 28 days compressive strength as compared to the control mortars. Reduction in 28 day water absorption and intrinsic air permeability of mortar was observed for mortar containing DSF up to $15 \%$ by weight of binder. Conclusion: DSF was determined to have large median particle size of $28.21 \mu \mathrm{m}$ and high amorphous silica content. Incorporation of DSF in mortar increases water demand of mix to achieve constant workability. Optimum level of cement replacement using DSF to ensure best compressive strength performance was found to be $7.5 \%$ by total weight of binder.
\end{abstract}

Key words: Densified silica fume, material characterisation, mechanical strength, air permeability, water absorption, Densified Silica Fume (DSF), partial cement replacement material, chemical composition, electrostatic precipitator, purity quartz, Portlandite produced, constituent material, particle clusters

\section{INTRODUCTION}

Silica fume which is also commonly referred to as microsilica or condensed silica fume is a by product of the manufacture of silicon or ferrosilicon alloys from high purity quartz and coal in a submerged arc electric furnace (Neville, 1996). The best method of reuse of the waste material is by incorporation as supplementary binder with ordinary Portland cement. Portland cement can be used parallel with silica fume as solidification and stabilizing agent (Patel and Pandey, 2009). There have been numerous research findings which has verified the fact that the incorporation of silica fume as partial cement replacement material in the production of structural concrete and mortar mixes contributed significantly towards enhancement in early strength gain rate, quality of aggregate-cement interface zone and pore structure of hardened concrete mixes (Duval and Kadri, 1998; Rao, 2001; 2003; Yajun and Cahyadi, 2003). These are attributable to microfiller effect and high rate of pozzolanic reaction of the extremely fine silica fume particles (median particle size, $\mathrm{d}_{50}<0.1 \mu \mathrm{m}$ ). Therefore, silica fume is commonly used as mineral admixture in the production of high strength concrete with compressive strength exceeding $60 \mathrm{MPa}$ (Ravichandran et al., 2009). Silica fume in its fresh form as collected from electrostatic precipitator has very low bulk density which incurs high shipping cost. Moreover, ultra fine particles of unprocessed silica fume poses serious respiratory health hazard which causes difficulty in handling. As a solution to the aforementioned problems, silica fume is commonly

Corresponding Author: Cheah Chee Ban, Department Building Technology, School of Housing, Building and Planning,

University Sains Malaysia, 11800 Penang, Malaysia Tel: +60 0164846502 Fax: +60 046576523 
supplied in the form of dry densified powder or slurry for use as constituent material in concrete and mortar (Diamond and Sahu, 2006). The slurried silica fume product is becoming rarely available while the use of Densified Silica Fume (DSF) is gaining popularity and it appears that almost all silica fume currently used in the manufacture of high performance concrete is in the form of dry densified powder (Diamond et al., 2004). The densification of silica fume particles was peformed at temperature much lower than melting point of silica fume particles whereby no additional bond formed between individual particles. However, upon being subjected to tumbling action during densification, progressive entanglement of clusters of silica fume particles occurred which resulted in formation of dense agglomerates (Diamond and Sahu, 2006). Agglomerated silica fume particle clusters has large diameter in the range of $10 \mu \mathrm{m}$ to several thousand microns as opposed to fresh silica fume with particle diameter ranging between 0.03-0.3 $\mu \mathrm{m}$ (Neville, 1996; Diamond et al., 2004). Such alteration in particle size of silica fume has adverse effect on its micro filler action in concrete and rate of secondary hydration between silica fume particles with Portlandite produced from primary hydration of cement (Yajun and Cahyadi, 2003).

In numerous past researches (Duval and Kadri, 1998; Rao, 2003; Toutanji and El-Korchi, 1995; Bhanja and Sengupta, 2005; Behnood and Ziari, 2008) performed to investigate performance of cement paste, concrete or mortar containing silica fume, the type of silica fume used as mineral admixture for fabrication of experimental specimens were not clearly specified. This is due to the assumption that the form of silica fume has no significant effect on its performance as secondary binder in concrete. In addition, it has been presumed that micro-structural changes imposed to silica fume particles by densification process are reversible upon mixing with other constituent materials of concrete. In reality, these assumptions are not true and the effect of densification process on engineering properties of silica fume is significant (Diamond and Sahu, 2006). Thorough understanding on hydration properties of densified silica fume becomes even more crucial in the mix design of very high strength concrete (compressive strength greater than $200 \mathrm{MPa}$ ) whereby careful selection of binder and quality of silica fume used may have significant effect on strength of concrete (Hamoush et al., 2010).

As referred to the current development in the use of silica fume as supplementary binder in concrete and mortar, there have been few research studies which focused on the engineering properties namely compressive strength and water absorption of concrete containing DSF as mineral admixture. Growing popularity of the use of DSF in the concrete and mortar production industry mandates better understanding on the characteristics of DSF and engineering properties of mortar or concrete produced by incorporation of DSF as mineral admixture. In addition, DSF modified mortar mixes has been widely used in the fabrication of versatile and high performance ferrocement structural panels (Kumar and Vidivelli, 2010). This is due to the enhanced durability and mechanical performance of DSF modified mortar which contributed to optimal consumption of constituent materials.

Hence, the aim of this study is to investigate the compressive strength and water absorption properties of high performance mortar containing DSF as mineral admixture. The experimental investigation also aimed to determine the optimum level of cement replacement using DSF in order to ensure highest strength and water absorption performance of mortar produced. Moreover, the best method of workability retention of fresh mortar containing DSF at various level of cement replacement was derived from this study.

\section{MATERIALS AND METHODS}

\section{Materials:}

Cement and Densified Silica Fume (DSF): ASTM Type I Portland Cement (PC) with median particle size of $3.9 \mu \mathrm{m}$, specific surface area of $1.0432 \mathrm{~m} \mathrm{~g} \mathrm{~g}^{-1}$ and specific gravity of 3.02 were used in this study. Both physical and chemical properties of cement used comply with specifications in ASTM C150 / C150M, (2009). DSF used in the study had median particle size of $28.21 \mu \mathrm{m}$, specific surface area of $0.2170 \mathrm{~m}^{2} \mathrm{~g}^{-1}$ and specific gravity of 2.28. The chemical composition and particle size grading of PC used are presented in Table 1 and Fig. 1 respectively. As can be observed in Fig. 1, DSF particles are coarser as compared to PC particles.

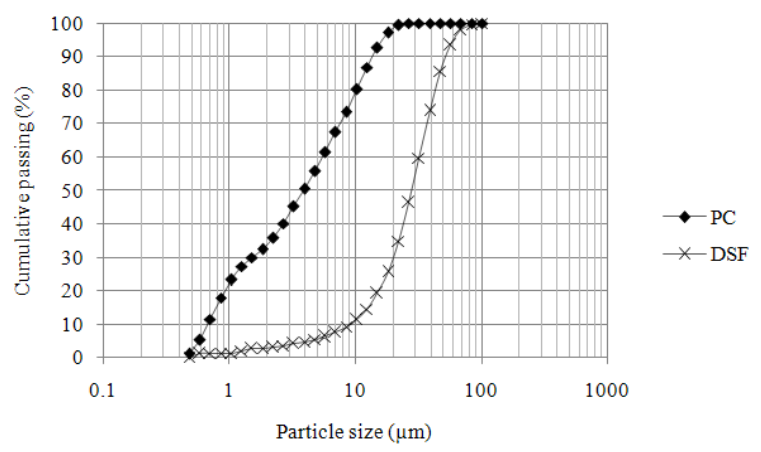

Fig. 1: Particle size distribution of PC and DSF 
Am. J. Applied Sci., 8 (1): 82-91, 2011

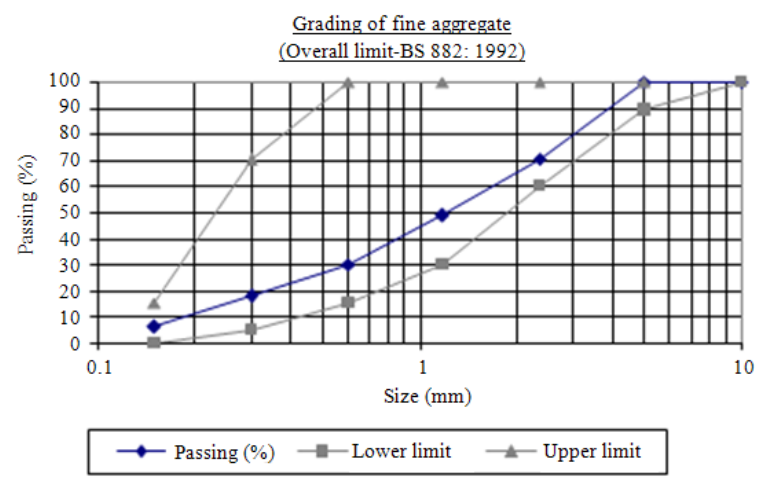

Fig. 2: Grading of fine aggregates

Table 1: Chemical compositions, loss on ignition (LOI) and physical properties of PC and DSF

\begin{tabular}{|c|c|c|}
\hline \multirow{2}{*}{$\begin{array}{l}\text { Chemical } \\
\text { Compound }\end{array}$} & \multicolumn{2}{|c|}{ Mass (\%) } \\
\hline & PC & DSF \\
\hline $\mathrm{MgO}$ & 1.500 & 0.600 \\
\hline $\mathrm{Al}_{2} \mathrm{O}_{3}$ & 3.600 & 1.200 \\
\hline $\mathrm{SiO}_{2}$ & 16.000 & 91.870 \\
\hline $\mathrm{P}_{2} \mathrm{O}_{5}$ & 0.057 & $\mathrm{n} / \mathrm{d}$ \\
\hline $\mathrm{SO}_{3}$ & 3.100 & 0.500 \\
\hline $\mathrm{K}_{2} \mathrm{O}$ & 0.340 & 0.800 \\
\hline $\mathrm{CaO}$ & 72.000 & 1.000 \\
\hline $\mathrm{TiO}_{2}$ & 0.170 & $\mathrm{n} / \mathrm{d}$ \\
\hline $\mathrm{MnO}$ & 0.028 & $\mathrm{n} / \mathrm{d}$ \\
\hline $\mathrm{Fe}_{2} \mathrm{O}_{3}$ & 2.900 & 2.000 \\
\hline $\mathrm{ZnO}$ & trace & $\mathrm{n} / \mathrm{d}$ \\
\hline $\mathrm{SrO}$ & 0.035 & $\mathrm{n} / \mathrm{d}$ \\
\hline $\mathrm{ZrO}_{2}$ & 0.018 & $\mathrm{n} / \mathrm{d}$ \\
\hline $\mathrm{PbO}$ & 0.012 & $\mathrm{n} / \mathrm{d}$ \\
\hline $\mathrm{Rb}_{2} \mathrm{O}$ & trace & $\mathrm{n} / \mathrm{d}$ \\
\hline $\mathrm{Na}_{2} \mathrm{O}$ & $\mathrm{n} / \mathrm{d}$ & 0.800 \\
\hline Loss on ignition (\%) & 2.53 & 4.96 \\
\hline \multicolumn{3}{|l|}{ Specific surface } \\
\hline Area $\left(m^{2} g^{-1}\right)$ & 1.0432 & 0.2170 \\
\hline Specific gravity & 3.02 & 2.30 \\
\hline Median particle & & \\
\hline diameter, $\mathrm{d}_{50}(\mu \mathrm{m})$ & 3.90 & 28.21 \\
\hline
\end{tabular}

Aggregates: Fine aggregate used were locally sourced quartzitic natural river sand in uncrushed form with specific gravity of 2.83 and maximum aggregate size of $5 \mathrm{~mm}$. Fine aggregates were dried to saturated surface dry condition prior to use as constituent material in mortar mixes. Fine aggregates were graded in accordance to BS812: Part 102 (1989) and grading of fine aggregates used was in compliance with overall grading limits of BS 882 (1992) as shown in Fig. 2. Fineness modulus of the fine aggregates was determined to be 3.26 .

Superplasticizer and mixing water: Aqueous solution of polycarboxylic ether by the commercial designation of Glenium Ace 388 was used as superplasticizer in this study. The superplasticizer was incorporated into mortar mixtures at constant dosage to maintain desired level of fresh mix workability. Potable water from local water supply network was used as mixing water for all mortar mixes produced.

\section{Methods:}

Characterisation of DSF and cement: Chemical compositions of DSF and PC were determined by XRay Fluorescence analytical method using X-ray spectrometer with the commercial name of Rigaku RIX3000. Mineral phases of oxide compounds detected from X-Ray Fluorescence analysis were identified by X-Ray diffraction method using Bruker X-Ray diffractometer. Loss On Ignition (LOI) of DSF and PC was determined in accordance to procedures prescribed in ASTM C311 (2007).

Particle size distribution, median particle size diameter $\left(\mathrm{d}_{50}\right)$ and specific surface area of both DSF and PC were determined by laser diffraction analysis using Malvern laser particle size analyzer. Applicability of laser diffraction technique as an alternative to the conventional Blaine permeability method for determination of specific surface area of cementitious materials was verified by previous research (Frias et al., 1991). Specific gravity values of the samples were determined using Le Chatelier Flask and procedures prescribed in ASTM C188 (2009). Kerosene was used as liquid medium for the assessment of specific gravity to avoid hydration of test samples during the test.

Mixture proportioning and mixing: The binder: sand ratio was maintained constant at 1:2.25 for all mortar mixes. The cement sand ratio was used as it was found to produce mortar with optimum compressive strength performance in earlier study (Cheah and Ramli, 2010). The PC binder was partially replaced using DSF at substitution level of 5, 7.5, 10, 12.5, 15, 17.5, 20, 25 and $25 \%$ by total binder's weight. For all mortar mixes with DSF content, water/binder ratio was adjusted while superplasticizer dosage was maintained at $1 \%$ of binder's weight to maintain desired mortar slump of $70 \pm 20 \mathrm{~mm}$, as prescribed in BS EN 206: Part 1 S2 (medium workability) slump range (Cheah and Ramli, 2010). Meanwhile, flow of all fresh mortars was maintained within range of $40 \pm 5 \%$ to ensure adequate workability of mix for proper compaction. The mix design of control mortar mixture (C) was performed using absolute volume method prescribed in design code ACI 211.1 (ACI 211.1, 1991; Ramli and Dawood, 2010) to achieve structural grade strength of $40 \mathrm{MPa}$ at the age of 28 days. In general, concrete or mortar mixes with compressive strength of $40 \mathrm{MPa}$ or higher are referred as high strength mixes (Saravanan et al., 2010). The composition of mortar mixes are summarised in Table 2. 
Am. J. Applied Sci., 8 (1): 82-91, 2011

Table 2: Proportion of constituent materials, bulk density and rheological properties of mortar mixes

\begin{tabular}{|c|c|c|c|c|c|c|c|c|c|}
\hline $\begin{array}{l}\text { Batch } \\
\text { designation }\end{array}$ & $\%$ DSF & $\begin{array}{l}\text { Cement } \\
\left(\mathrm{kg} \mathrm{m}^{-3}\right)\end{array}$ & $\begin{array}{l}\text { DSF } \\
\left(\mathrm{kg} \mathrm{m}^{-3}\right)\end{array}$ & $\begin{array}{l}\text { Sand } \\
\left(\mathrm{kg} \mathrm{m}^{-3}\right)\end{array}$ & $\begin{array}{l}\text { Water } \\
\left(\mathrm{kg} \mathrm{m}^{-3}\right)\end{array}$ & $\begin{array}{l}\text { SP } \\
\text { dosage (\%) }\end{array}$ & $\mathrm{w} / \mathrm{c}$ & $\begin{array}{l}\text { Mortar } \\
\text { flow (\%) }\end{array}$ & $\begin{array}{l}\text { Slump } \\
(\mathrm{mm})\end{array}$ \\
\hline $\mathrm{C}$ & 0.0 & 708 & 0 & 1593 & 198 & 1.00 & 0.28 & 38.46 & 70 \\
\hline W5 & 5.0 & 673 & 35 & 1593 & 219 & 1.00 & 0.31 & 41.53 & 80 \\
\hline W7.5 & 7.5 & 655 & 53 & 1593 & 227 & 1.00 & 0.32 & 37.99 & 85 \\
\hline W10 & 10.0 & 637 & 71 & 1593 & 234 & 1.00 & 0.33 & 33.82 & 60 \\
\hline W12.5 & 12.5 & 620 & 89 & 1593 & 244 & 1.00 & 0.35 & 44.15 & 50 \\
\hline W15 & 15.0 & 602 & 106 & 1593 & 248 & 1.00 & 0.35 & 35.96 & 60 \\
\hline W17.5 & 17.5 & 584 & 124 & 1593 & 262 & 1.00 & 0.37 & 41.75 & 60 \\
\hline W20 & 20.0 & 566 & 142 & 1593 & 269 & 1.00 & 0.38 & 35.48 & 65 \\
\hline W25 & 25.0 & 531 & 177 & 1593 & 290 & 1.00 & 0.41 & 38.94 & 60 \\
\hline
\end{tabular}

Mortar mixing and curing: Each batch of mortar was produced using an epicyclic type mechanical mixer complying with specifications prescribed in standard code of practice ASTM C305 (2006). During mixing, DSF and PC were initially homogenized at low mixing speed for duration of 10 min prior to addition of other constituent materials (Abu-Lebdeh et al., 2010). Further mixing sequences and durations were performed in accordance to standard procedures prescribed in ASTM Standard C305 (Cheah and Ramli, 2010).

Rheological properties: ASTM Flow test was performed on fresh mortar using flow table complying with specifications prescribed in ASTM Standard C230 and standard testing procedures described in ASTM Standard C109. Besides, slump values of the mortar mixes were determined by slump test performed in accordance to procedures prescribed in BS 1881: Part 102 (Cheah and Ramli, 2010). Fresh mortar flow and slump values obtained are presented in Table 2 .

Compressive strength, Ultrasonic Pulse Velocity (UPV) and bulk density tests: Mortar cube specimens with edge dimensions of $50 \mathrm{~mm}$ were moulded, cured and tested in accordance to procedures described in ASTM Standard C109 (2008) for determination of compressive strength of hardened mortar mixtures produced. All mortar specimens fabricated were cured in lime saturated water for duration of 3, 7, 14 and 28 days prior being subjected to compression test. The reported compressive strengths at given age of mortar are the average of three number of specimens tested.

Propagation velocities of transmitted ultrasonic pulse through hardened mortar mixtures were determined using an electrical pulse generator and testing methods prescribed in BS EN 12504-4 (2004) on a representative mortar prism specimen with dimensions of $100 \times 100 \times 500 \mathrm{~mm}$. Transmission of ultrasonic pulse was performed by direct transmission method through constant path length of $100 \mathrm{~mm}$ between transducers. Bulk densities of hardened mortars were determined in accordance to methods in BS 1881: Part 114 (1983).

\section{RESULTS AND DISCUSSION}

\section{Characterisation of DSF:}

Physical properties of DSF: Particle grading curves of PC and DSF are presented in Fig. 1. Median particle size of ground DSF was found to be $28.21 \mu \mathrm{m}$ and corresponding specific surface area of $0.2170 \mathrm{~m}^{2} \mathrm{~g}^{-1}$. In comparison to PC sample which have median particle size of $3.19 \mu \mathrm{m}$ and specific surface area of $1.0432 \mathrm{~m}^{2}$ $\mathrm{g}^{-1}$, it is apparent that DSF particles is much coarser than PC particles. The observation is consistent with findings of other researchers (Yajun and Cahyadi, 2003) and serves as a further evidence that densification of silica fume results in agglomeration of silica fume clustered particles forming large diameter agglomerates. By using laser diffraction surface area measurement technique, the measured specific surface area of DSF is the specific surface area of silica fume agglomerates which is much lower as compared to lower limit of $15 \mathrm{~m}^{2} \mathrm{~g}^{-1}$ prescribed in ASTM Standards C1240 (2010). Specific gravity of DSF particles was determined to be 2.28 .

Chemical composition and solid state of DSF: The results of X-ray fluorescence analysis on DSF are presented in Table 1. From the test results, it can be observed that the dominant oxide compound present in DSF is silica which constitutes $90 \%$ by total weight of the material. Silica content of DSF is in compliance with limits predefined by ASTM Standards C1240 (2010) for use as constituent material in cementitious mixes. The other oxide compounds namely $\mathrm{MgO}$, $\mathrm{Al}_{2} \mathrm{O}_{3}, \mathrm{SO}_{3}, \mathrm{CaO}, \mathrm{Fe}_{2} \mathrm{O}_{3}$ and $\mathrm{N}_{2} \mathrm{O}$ were detected in minor composition as indicated in Table 1 . The sum of composition of essential pozzolanic oxide namely $\mathrm{SiO}_{2}$, $\mathrm{Al}_{2} \mathrm{O}_{3}$ and $\mathrm{Fe}_{2} \mathrm{O}_{3}$ of DSF was found to be $93.2 \%$. Loss on ignition of DSF was found to be $4.96 \%$ which is in 
Am. J. Applied Sci., 8 (1): 82-91, 2011

compliance with upper limit prescribed in ASTM Standards C1240 (2010).

The X-Ray Diffraction pattern of DSF is presented in Fig. 3. The XRD pattern of DSF is consistent with pattern obtained by other researchers (Salas et al., 2009; Mostafa et al., 2001; Chong et al., 2009). Broad scattering peak of the XRD spectrum between $24^{\circ}$ and $37^{\circ}$ on the $2 \theta$ scale indicates that the silica composition of DSF was in pure amorphous state (Mostafa et al., 2001; Lin et al., 2003).

Superplasticizer requirement and workability of fresh mortar: The flow and slump values of fresh mortar produced along with their respective required water-binder ratio to achieve slump within the range of $70 \pm 20 \mathrm{~mm}$ are presented in Table 2. The results indicate that as level of replacement with DSF increased from $0 \%$ (Control mortar) to $25 \%$, water demand of the mixes increases gradually from $\mathrm{w} / \mathrm{b}$ of $0.28-0.41$ in order to maintain constant level of mix plasticity for constant superplasticizer dosage of $1 \%$ of total binder's weight.

Slump and flow results indicated that both slump and flow of mortar mixes could be affectively controlled within desired range of $70 \pm 20 \mathrm{~mm}$ and $40 \pm 5 \%$ respectively by adjustment in water-binder ratio.

Bulk density of hardened mortar: Bulk density of mortar with various cement replacement levels using DSF is presented in Table 3. Generally, a marginal increase in bulk density of mortar was observed when silica fume was incorporated at cement replacement level of $5 \%$ as compared to the control mortar mix (C). Higher bulk density of mortar at 5\% level of replacement can be attributed to denser cement paste matrix and improved plasticity of fresh mortar. On further increase in level of cement replacement beyond
$5 \%$ up to $25 \%$, a gradual decrease in bulk density of mortar could be noted. The observation is probably due to lower specific gravity of DSF particle as compared to PC particles.

Compressive strength and Ultrasonic Pulse Velocity (UPV): Compressive strengths and normalized compressive strengths of mortar with various DSF content are compared to PC mortar in Table 3 . Generally, all mortar with DSF content exhibited progressive increase in normalized compressive strength with increasing age of mortar from 3 days up to 28 days. The observation indicates presence of active pozzolanic reaction within the mixes between amorphous silica compound of DSF and hydration product of PC. At the age of 3 days, mortar containing DSF at replacement level between 5, 7.5 and 10\% exhibited higher compressive strength as compared to the control mortar. Enhancement in early age strength of mortar by incorporation of DSF at the aforementioned levels of replacement is due to microfiller effect of the fine fraction of silica fume particles within cement paste matrix and the aggregate-cement paste interfacial zone. Combination of denser particle packing of cement paste and better aggregate-cement interface quality resulting from the micro-filler effect contributed towards enhanced compressive strength performance of DSF mortar at early age of curing (Neville, 1996). At the same age, incorporation of silica fume at higher level of cement replacement beyond $10 \%$ was observed to have little effect in further enhancement in strength of mortar because all the micro pores of cement paste and cement-aggregate interfacial zone had been filled.

Laboratory results on performance of DSF mortar mixes are presented graphically in Fig.4-7.

Table 3: Compressive strengths and bulk densities of hardened mortar mixtures

\begin{tabular}{|c|c|c|c|c|c|c|c|c|c|}
\hline \multirow[b]{2}{*}{ Batch No. } & \multirow[b]{2}{*}{$\begin{array}{l}\text { Bulk density } \\
\left(\mathrm{kg} \mathrm{m}^{-3}\right)\end{array}$} & \multicolumn{8}{|c|}{ Compressive strength (MPa)-normalized } \\
\hline & & 3 Days & $\begin{array}{l}\text { Normalized } \\
(\%)\end{array}$ & 7 Days & $\begin{array}{l}\text { Normalized } \\
(\%)\end{array}$ & 14 Days & $\begin{array}{l}\text { Normalized } \\
(\%)\end{array}$ & 28 Days & $\begin{array}{l}\text { Normalized } \\
(\%)\end{array}$ \\
\hline $\mathrm{C}$ & 2270 & 39.20 & 100.0 & 42.02 & 100.0 & 42.63 & 100.0 & 43.16 & 100.0 \\
\hline W5 & 2277 & 44.01 & 112.3 & 50.40 & 119.9 & 51.72 & 121.3 & 54.31 & 125.8 \\
\hline W7.5 & 2246 & 44.49 & 113.5 & 51.92 & 123.6 & 54.06 & 126.8 & 55.46 & 128.5 \\
\hline W10 & 2258 & 41.74 & 106.5 & 48.93 & 116.4 & 52.44 & 123.0 & 55.84 & 129.4 \\
\hline W12.5 & 2187 & 38.20 & 97.4 & 41.80 & 99.5 & 45.89 & 107.6 & 47.06 & 109.0 \\
\hline W15 & 2202 & 34.09 & 87.0 & 44.25 & 105.3 & 47.64 & 111.8 & 49.44 & 114.6 \\
\hline W17.5 & 2181 & 31.45 & 80.2 & 38.61 & 91.9 & 44.63 & 104.7 & 44.68 & 103.5 \\
\hline W20 & 2172 & 33.57 & 85.6 & 44.20 & 105.2 & 48.33 & 113.4 & 51.85 & 120.1 \\
\hline W25 & 2148 & 29.12 & 74.3 & 44.16 & 105.1 & 46.53 & 109.1 & 49.22 & 114.0 \\
\hline
\end{tabular}


Am. J. Applied Sci., 8 (1): 82-91, 2011

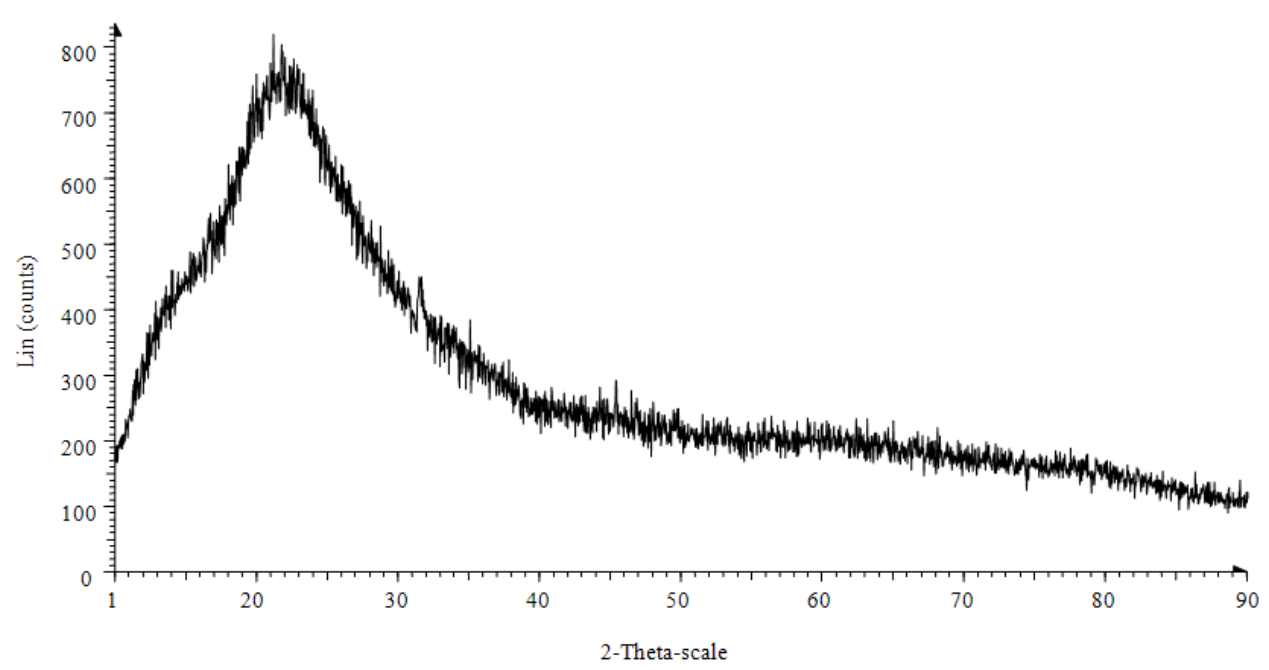

Fig. 3: XRD pattern of DSF

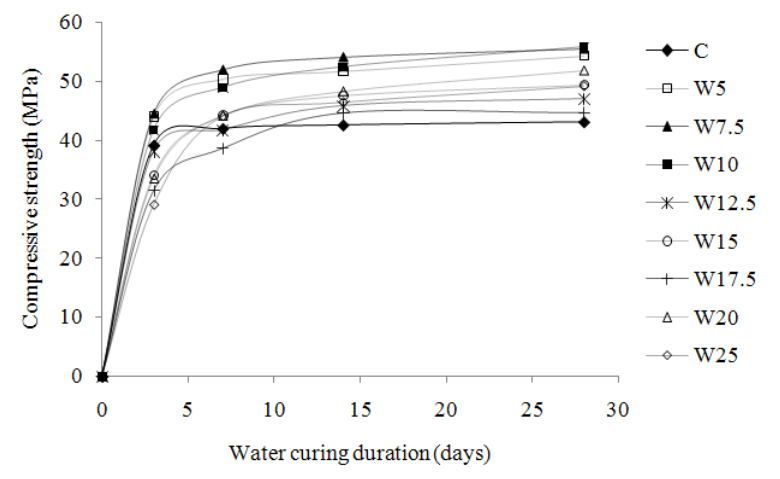

Fig. 4: Compressive strength development behaviour of DSF mortar

From Fig. 4, it can be observed that rate of strength development for hardened DSF mortar between the age of 7 and 14 days was significantly higher as compared to the control mortar. By the age of 14 days, compressive strength of mortar mixes with DSF content of up to $25 \%$ had surpassed the compressive strength of the control mortar. Mortar containing $7.5 \%$ of DSF (W7.5) consistently exhibited optimum compressive strength of $44.49 \mathrm{MPa}, 51.92 \mathrm{MPa}$ and $54.06 \mathrm{MPa}$ for curing duration of 3,7 and 14 days respectively. Though mortar with DSF content of $10 \%$ (W10) exhibited lower compressive strength as compared to W7.5 mortar at early ages up to 14 days, by the age of 28 days, W10 mortar exhibited compressive strength of $55.84 \mathrm{MPa}$ which is marginally higher as compared to the compressive strength of W7.5 mortar which was recorded at 55.46MPa. This is due to high rate of strength gain of W10 mortar between curing age of 14 and 28 days probably contributed by rigorous pozzolanic reaction in the presence of significant amount of amorphous silica within the mix.

From Fig. 5, it can be observed that at a given strength, mortar containing DSF at all level of cement replacement exhibited lower ultrasonic pulse velocity as compared to the control mortar. The observation indicates that the control mortar mix was less porous and denser than DSF mortar mixes (Hamid et al., 2010). The observation is consistent with measured mortar densities as tabulated in Table 3. Among DSF mortars, lower values of ultrasonic pulse velocity were recorded for mortar with higher level of cement replacement by DSF at a given strength. This is probably due to higher degree of porosity of hardened mortar as water content of the mixes was raised with increasing level of cement replacement in order to maintain constant level of mix workability.

Regression analysis on the mean compressive strength and ultrasonic pulse velocities of mortar mixes reveals a strong correlation between compressive strength of mortar with ultrasonic pulse velocity. Results of regression analysis indicated that mean compressive strength of mortar mixes is related ultrasonic pulse velocity by the following parabolic equations.

$$
\begin{aligned}
& C: y=-35.33 x^{2}+328.0 x-717.7, R^{2}=0.999 \\
& \text { W5: } y=69.48 x^{2}-562.7 x+1181, R^{2}=0.978 \\
& \text { W7.5: } y=-97.79 x^{2}+894.3 x-1987, R^{2}=0.990 \\
& \text { W10: } y=-97.32 x^{2}+879.9 x-1935, R^{2}=0.848
\end{aligned}
$$


Am. J. Applied Sci., 8 (1): 82-91, 2011

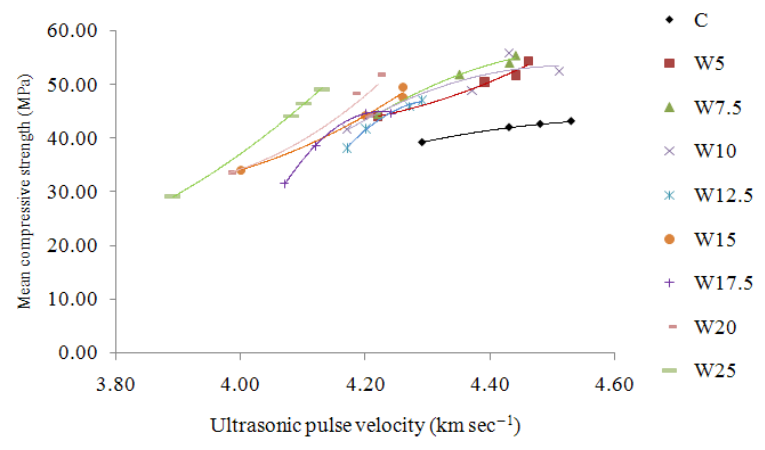

Fig. 5: Correlation between mean compressive strength and ultrasonic pulse velocity of DSF mortar

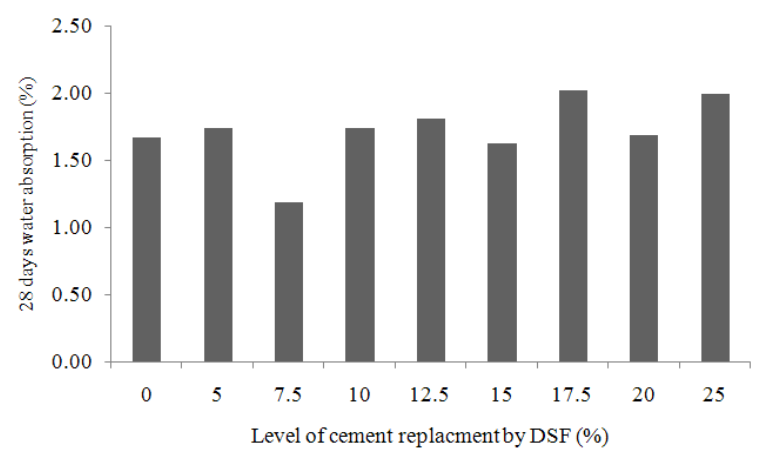

Fig. 6: 28-Days water absorption of DSF mortar

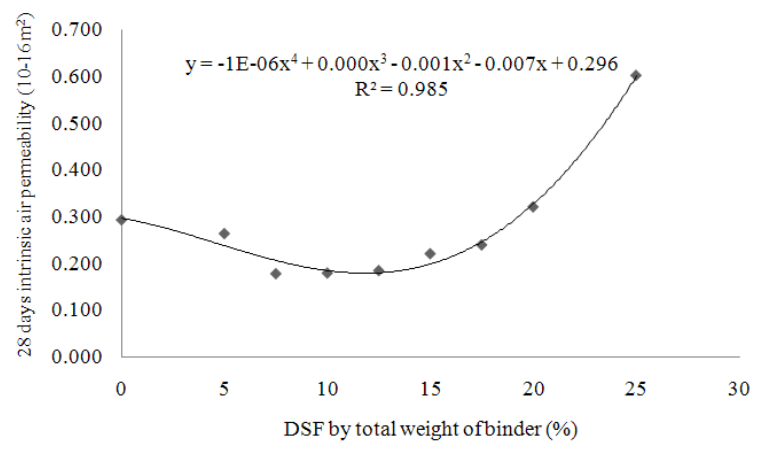

Fig. 7: Intrinsic air permeability of DSF mortar

$$
\begin{aligned}
& \text { W12.5: } y=-405.5 x^{2}+3501 . x-7511, R^{2}=0.995 \\
& W 15: y=79.90 x^{2}-604.4 x+1173, R^{2}=0.988 \\
& W 17.5: y=-563.0 x^{2}+4757 . x-10004, R^{2}=0.999 \\
& \text { W20: } y=142.2 x^{2}-1097 . x+2148, R^{2}=0.879 \\
& \text { W25: } y=81.21 x^{2}-567.2 x+1006, R^{2}=0.999
\end{aligned}
$$

Where:

$\mathrm{y}=$ Compressive strength, $\mathrm{MPa}$

$\mathrm{x}=$ Ultrasonic pulse velocity, $\mathrm{km} \mathrm{sec}^{-1}$

Water absorption: Figure 6 shows the 28-day water absorption of mortar with various DSF content. From Fig. 6, it can be noted that mortar with DSF content of 7.5\% (W7.5) exhibited lowest water absorption of $1.19 \%$. Meanwhile water absorption of other mortar mixes with DSF content up to $25 \%$ by total weight of binder did show significant variation with values ranging between 1.62 and $2.02 \%$. Water absorption of mortar containing 15 and 20\% DSF were observed to be lower as compared to the control mortar. Meanwhile, mortar with DSF content of 5, 10, 12.5, 17.5 and 25\% were relatively lower than the control mortar. However, values of water absorption for all mortar containing DSF are well below $10 \%$ which is the upper limit allowable for most construction materials (Udoeyo et al., 2006).

Intrinsic air permeability: At the age of 28 days, a marked decrease in degree of air permeability was observed for mortar mixes containing DSF up to replacement level of $17.5 \%$ as compared to the control mortar as can be seen in Fig. 7. Mortar with 7.5\% DSF by total weight of binder exhibited lowest 28 days intrinsic air permeability value of $0.178 \times 10^{-16} \mathrm{~m}^{2}$. For level of cement replacement with DSF beyond 7.5\% up to $25 \%$, a gradual increase in values of intrinsic air permeability could be observed. However at level of cement replacement by HCWA up to $17.5 \%$, intrinsic air permeability of mortar specimen was found to be $0.24 \times 10^{-16} \mathrm{~m}^{2}$ which is still lower as compared to $0.293 \times 10^{-16} \mathrm{~m}^{2}$ exhibited by the control mortar specimen. Intrinsic air permeability of ortar specimens with DSF content of 5, 10, 12.5, 15, 20 and 25\% was found to be $0.264 \times 10^{-16} \mathrm{~m}^{2}, \quad 0.179 \times 10^{-16} \mathrm{~m}^{2}$, $0.184 \times 10^{-16} \mathrm{~m}^{2}, 0.221 \times 10^{-16} \mathrm{~m}^{2}, 0.321 \times 10^{-16} \mathrm{~m}^{2}$ and $0.600 \times 10^{-16} \mathrm{~m}^{2}$, respectively. The gradual increase in value of intrinsic air permeability when the level of cement replacement with HCWA was increased beyond $7.5 \%$ is probably due to dominating effect of microfiller action of HCWA particles in refinement of pore structure over pozzolanic reaction of HCWA at early age of 28 days. Hence, further increase in DSF content and corresponding reactive silica amount did not contribute towards reduction in intrinsic air permeability of mix at this age. Regression analysis revealed a strong correlation between intrinsic air permeability of DSF mortar with level of cement replacement with DSF. Value of intrinsic air permeability of hardened mortar mixes can be accurately predicted using the following equation: 
Am. J. Applied Sci., 8 (1): 82-91, 2011

$y=-10^{-6} x^{4}-0.001 x^{2}-0.007 x+0.296, R^{2}=0.985$

Where:

$\mathrm{y}=$ Intrinsic air permeability $\left(\mathrm{m}^{2}\right)$

$\mathrm{x}=$ Level of cement replacement by DSF (\%)

\section{CONCLUSION}

As referred to results acquired throughout the laboratory investigation, the following conclusions can be derived:

- DSF consists mainly of amorphous silica with median particle size of $28.21 \mu \mathrm{m}$

- The use of DSF in mortar mix increased water demand of the mix to achieve a given level of workability

- Workability of mortar mix with various DSF content up to $25 \%$ by weight of binder in term of slump and flow can be optimally controlled within a given range by variation in water binder ratio of mix without adversely affecting 28 days compressive strength of the mix

- Optimum enhancement in the rate of early strength gain could be achieved by incorporation of DSF as partial cement replacement material at $7.5 \%$ by total weight of binder

- The use of DSF as partial cement replacement material up to $25 \%$ by weight of binder enhanced 28 day strength of mortar

- The level of cement replacement using DSF for optimum compressive strength performance is $7.5 \%$ by weight of binder

- Incorporation of DSF as cement replacement material up to $25 \%$ by total weight of binder did not have significant adverse effect on water absorption of mortar

- Highest impermeability of hardened mortar against penetration of air hence best durability performance could be achieved by incorporation of DSF in the mix at cement replacement level of $7.5 \%$ by total weight of binder

\section{ACKNOWLEDGEMENT}

The research study was jointly funded by University Sains Malaysia Fellowship Programme, University Sains Malaysia Research University Postgraduate Research Grant Scheme (USM-RUPRGS) and research grant of the second author.

\section{REFERENCES}

Abu-Lebdeh, T., S. Hamoush and B. Zornig, 2010. Rate effect on pullout behavior of steel fibers embedded in very-high strength concrete. Am. J. Eng. Applied Sci., 3: 454-463. DOI: 10.3844/ajeassp.2010.454.463

ACI 211.1, 1991. Standard practice for selecting proportions for normal, heavyweight and mass concrete.

http://aec.ihs.com/document/abstract/LIJCFBAAA AAAAAAA

ASTM Standard C109, 2008. Test method for compressive strength of hydraulic cement mortars (Using 2-in. or [50-mm] cube specimens). Annual Book of ASTM Standards. http://www.astm.org/Standards/C109.htm

ASTM Standards C1240, 2010. Standard specification for silica fume used in cementitious mixtures. Annual Book of ASTM Standards. http://www.astm.org/Standards/C1240.htm

ASTM C150 / C150M, 2009. Standard Specifications for portland cement. annual book of ASTM standards.

http://www.astm.org/Standards/C150.htm

ASTM C188, 2009. Standard Test method for density of hydraulic cement. Annual Book of ASTM Standards.

http://www.astm.org/Standards/C188.htm

ASTM C305, 2006. Standard Practice for mechanical mixing of hydraulic cement pastes and mortars of plastic consistency. Annual Book of ASTM Standards.

http://www.astm.org/Standards/C305.htm

ASTM C311, 2007. Standard test method for sampling and testing fly ash or natural pozzolans for use in Portland cement concrete. Annual Book of ASTM Standards. http://www.astm.org/Standards/C311.htm

Behnood, A. and H. Ziari, 2008. Effects of silica fume addition and water to cement ratio on the properties of high-strength concrete after exposure to high temperatures. Cement Concrete Compos., 30: 106-112. DOI: 10.1016/j.cemconcomp.2007.06.003

Bhanja, S. and B. Sengupta, 2005. Influence of silica fume on the tensile strength of concrete. Cement Concrete Res., 35: 743-747. DOI: 10.1016/j.cemconres.2004.05.024

BS 1881: Part 114, 1983. Testing concrete. Methods for determination of density of hardened concrete. British Standards Institution, London. http://www.techstreet.com/standards/BS/1881_114 _1983?product_id=1100507 
BS 882, 1992. Specification for aggregates from natural sources for concrete. British Standards Institution, London. $\quad$ http://www.techstreet.com/cgibin/detail?doc_no=BS\%7C882_1992\&product_id= 1107511

BS EN 12504-4, 2004. Testing concrete in structures. Determination of ultrasonic pulse velocity. http://products.ihs.com/cis/Doc.aspx?AuthCode=\& DocNum $=275284$

Cheah, C.B. and M. Ramli, 2010. Optimization of mix proportion of high performance mortar for structural applications. Am. J. Eng. Applied Sci., 3: 643-649. DOI: 10.3844/ajeassp.2010.643.649

Chong, G.H., R. Yunus, N. Abdullah, T.S.Y. Choong and S. Spotar, 2009. Coating and encapsulation of nanoparticles using supercritical antisolvent. Am. J. Applied Sci., 6: 1352-1358. DOI: 10.3844/ajassp.2009.1352.1358

Diamond, S. and S. Sahu, 2006. Densified silica fume: Particle sizes and dispersion in concrete. Mater. Struct., 39: 849-859. DOI: 10.1617/s11527-0069087-y

Diamond, S., S. Sahu and N. Thaulow, 2004. Reaction products of densified silica fume agglomerates in concrete. Cement Concrete Res., 34: 1625-1632. DOI: 10.1016/j.cemconres.2004.01.031

Duval, R. and E.H. Kadri, 1998. Influence of silica fume on the workability and the compressive strength of high-performance concretes. Cement Concrete Res., 28: 533-547. DOI: 10.1016/S00088846(98)00010-6

Frias, M., M.I. Sanchez de Rojas, M.P. Luxan and N. Garcia, 1991. Determination of specific surface area by the laser diffraction technique: Comparison with the Blaine permeability method. Cement Concrete Res., 21: 709-717. DOI: 10.1016/00088846(91)90165-E

Hamid, R., K.M. Yusof and M.F.M. Zain, 2010. A combined ultrasound method applied to high performance concrete with silica fume. Construct. Buil. Mater., 24: 94-98. DOI: 10.1016/j.conbuildmat.2009.08.012

Hamoush, S., T. Abu-Lebdeh, T. Cummins and B. Zornig, 2010. Pullout characterizations of various steel fibers embedded in very high-strength concrete. Am. J. Eng. Applied Sci., 3: 418-426. DOI: 10.3844/ajeassp.2010.418.426

Kumar, D.R. and B. Vidivelli, 2010. Acrylic rubber latex in ferrocement for strengthening reinforced concrete beams. Am. J. Eng. Applied Sci., 3: 277-285. DOI: 10.3844/ajeassp.2010.277.285
Lin, K.L., K.S. Wang, B.Y. Tzeng and C.Y. Lin, 2003. The reuse of municipal solid waste incinerator fly ash slag as a cement substitute. Resources, Conservat. Recycl., 39: 315-324. DOI: 10.1016/S0921-3449(02)00172-6

Mostafa, N.Y., S.A.S. El-Hemaly, E.I. Al-Wakeel, S.A. El-Korashy and P.W. Brown, 2001. Characterization and evaluation of the pozzolanic activity of Egyptian industrial by-products: I: Silica fume and dealuminated kaolin. Cement Concrete Res., 31: 467-474. DOI: 10.1016/S00088846(00)00485-3

Neville, A.M., 1996. Properties of Concrete. 4th Edn., John Wiley and Sons, New York, ISBN: 0470235276, pp: 844.

Patel, H. and S. Pandey, 2009. Exploring the reuse potential of chemical sludge from textile wastewater treatment plants in India-a hazardous waste. Am. J. Environ. Sci., 5: 106-110. DOI: 10.3844/ajessp.2009.106.110

Ramli, M. and E.T. Dawood, 2010. Effects of palm fiber on the mechanical properties of lightweight concrete crushed brick. Am. J. Eng. Applied Sci., 3: 489-493. DOI: 10.3844/ajeassp.2010.489.493

Rao, G.A., 2001. Development of strength with age of mortars containing silica fume. Cement Concrete Res., 31: 1141-1146. DOI: 10.1016/S00088846(01)00540-3

Rao, G.A., 2003. Investigations on the performance of silica fume-incorporated cement pastes and mortars. Cement Concrete Res., 33: 1765-1770. DOI: 10.1016/S0008-8846(03)00171-6

Ravichandran, A., K. Suguna and P.N. Ragunath, 2009. Strength modeling of high-strength concrete with hybrid fiber reinforcement. Am. J. Applied Sci., 6: 219-223. DOI: 10.3844/ajassp.2009.219.223

Salas, A., S. Delvasto, R.M. de Gutierrez and D. Lange, 2009. Comparison of two processes for treating rice husk ash for use in high performance concrete. Cement Concrete Res., 39: 773-778. DOI: 10.1016/j.cemconres.2009.05.006

Saravanan, J., K. Suguna and P.N. Raghunath, 2010. Confined high strength concrete columns: An experimental study. Am. J. Eng. Applied Sci., 3: 133-137. DOI: 10.3844/ajeassp.2010.133.137

Toutanji, H.A. and T. El-Korchi, 1995. The influence of silica fume on the compressive strength of cement paste and mortar. Cement Concrete Res., 25: 15911602. DOI: 10.1016/0008-8846(95)00152-3 
Udoeyo, F.F., H. Inyang, D.T. Young and E.E. Oparadu, 2006. Potential of wood waste ash as an additive in concrete. J. Mater. Civil Eng., 18: 605-611. http://link.aip.org/link/?QMT/18/605/1
Yajun, J. and J.H. Cahyadi, 2003. Effects of densified silica fume on microstructure and compressive strength of blended cement pastes. Cement Concrete Res., 33: 1543-1548. DOI: 10.1016/S0008-8846(03)00100-5 